\title{
Estimation of scour for bridges in Illinois
}

\author{
R. Chaulagai, P. Safarian Bahri, A. Osouli \\ Southern Illinois University Edwardsville, IL, USA
}

\begin{abstract}
Scour development around bridge piers is one of the main reasons for bridge failure. This paper presents the comparison of ultimate pier and contraction scour depth for cohesive soils at nine bridge sites in Illinois. Results obtained from common prediction methods such as SRICOS, Hydraulic Engineering Circular No. 18 (HEC - 18), Florida Department of Transportation (FDOT) and reduction factor method were compared. All bridge piers have round nose shape except one. SRICOS and FDOT method predicted the lowest and highest ultimate depths of scour, respectively. Measured scour depth for real time obtained from the field was also compared with the ones predicted by SRICOS and modified HEC - 18 methods. In this case, SRICOS method and modified HEC - 18 predictions were in reasonable agreement with each other, however, they both were conservative.
\end{abstract}

\section{INTRODUCTION}

More than $60 \%$ of bridge failures in the United States are due to scouring and only $2 \%$ of the failures are caused by earthquakes (Shirole \& Holt 1991). Many studies have been done on bridge scour predictions during the past decades. Most of the studies prior to 1999 were performed on non-cohesive materials. The most common prediction method was proposed by HEC -18 and was later modified making it applicable for cohesive material.

Scour is the process of removal of soil from the bed and banks of a river by the erosive action of flowing water. Granular soil has a high erodibility property and can reach to the ultimate scour depth within a single flood event, whereas cohesive material has a low erodibility property and can take a decade or longer to reach an ultimate scour depth (Arneson et al., 2012). In the process of water flowing over the soil, shear stress is induced in the soil water interface and the scour occurs when the induced shear stress is greater than critical shear stress - shear stress acted upon soil by flowing water at which erosion is initiated. Abutment scour, contraction scour, and pier scour are some common types of scour that occurs in the bed and banks of rivers (Wang 2004). However, this paper, is focused on the pier and contraction scour that had happened at nine bridge sites in Illinois since their construction to 2005 .
Contraction scour occurs when there is reduction in the flow area either by construction of the bridge or embankments or an obstacle. It is apparent form the hydraulic principle that, when the area of flow is reduced, velocity and induced shear stress are increased, which ultimately leads to erosion of bed materials. Contraction scour occurs either in the entire width of a river or only in some portion of the river width depending upon the flow (Briaud et al., 2008). On the other hand, pier scour is the process of removal of soil from the vicinity of the pier. Water flowing around the pier produces horseshoe vortices and wake vortices at the base and around the pier, respectively, which initiate scour. The depth and the shape of the pier scour are fundamentally dependent on pier geometry (Briaud et al., 2011). In this study, nine bridge sites are considered, out of which eight sites have a round nose pier shape and the remaining pier has square nose shape.

In addition to HEC - 18, there are some other relevant studies available. Briaud et al. (1999) proposed a method for prediction of scour rates in cohesive soils around bridge piers called SRICOS. For this method, the Erosion Function Apparatus (EFA) was developed to measure the scouring rate of retrieved materials in Shelby tubes. The SRICOS method was then developed further for predicting contraction scour for simple and complex piers as well as being able to handle the multi-flood hydrograph and multilayer soil systems (Wang, 2004).

Ghelradi (2004) compared the HEC - 18 method for non-cohesive soils with the SRICOS method for 
retrieved samples from five Maryland bridge sites. It was concluded that SRICOS predicts smaller values for pier scour in comparison with the HEC - 18 method which is typically used for non-cohesive materials. In non-cohesive materials scour happens during a relatively short period of time, whereas in cohesive materials time plays an important role, as the maximum depth of scour might not be reached even in decades. Briaud (2014) did a study on time rate of scour prediction and compared the SRICOS predicted results with measured values to validate the SRICOS method.

In 2012, the fifth edition of HEC - 18 included a modified version of the SRICOS method in its manual for cohesive material scour prediction. In the same edition, methods proposed by the Florida department of transportation along with the old HEC - 18 method for non-cohesive material were also presented. In this paper, the HEC - 18 method for non-cohesive soil and cohesive soil are represented as old HEC - 18 and modified HEC - 18, respectively. Since the use of the old HEC - 18 method is very common, and usually predicts high scour depth, there are some studies that try to reduce the predicted scour depth for cohesive material from the old HEC - 18 method by introducing reduction factors. Straub \& Over (2013) defined reduction factors based on unconfined compressive strength of soil. These reduction factors are applied to the predicted ultimate pier and contraction scour depth obtained from the old HEC - 18 method and compared with the modified HEC - 18 method.

In this paper, a comparative study of ultimate depth of scour (i.e., pier and contraction) through various scour prediction methods has been conducted. These methods include the SRICOS method, old HEC - 18 method, modified HEC - 18 method, Florida Department of Transportation method and the reduction factor method. The predicted pier and contraction scour using the cohesive methods (i.e., SRICOS and modified HEC - 18), with measured scour depth over time, from the bridge construction period to 2005 has also been studied and compared. The measured scour depth along with pier and hydraulic data of nine bridge sites were collected from Straub et al. (2010 \& 2013).

\section{BRIDGE STIE AND PREDICTION METHODS}

Hydraulics and river geometry data for the nine bridge sites in Illinois are shown in Table 1 and Table 2 . These data were used to predict ultimate pier scour and contraction scour depth and also for comparison of predicted scour with measured scour depth for real time.

Figure 1 shows the simplified channel cross section and all parameters given in Table 2. It is used for the prediction of ultimate pier and contraction scour depth using the cohesive methods (i.e., SRICOS and modified HEC - 18). In this figure, ' $\mathrm{y}_{0}$ ' and ' $\mathrm{y}_{1}$ ', are the flow depth at the pier location and upstream of the pier, respectively while ' $L$ ' and ' $a$ ' are the length and width of the pier.

a)

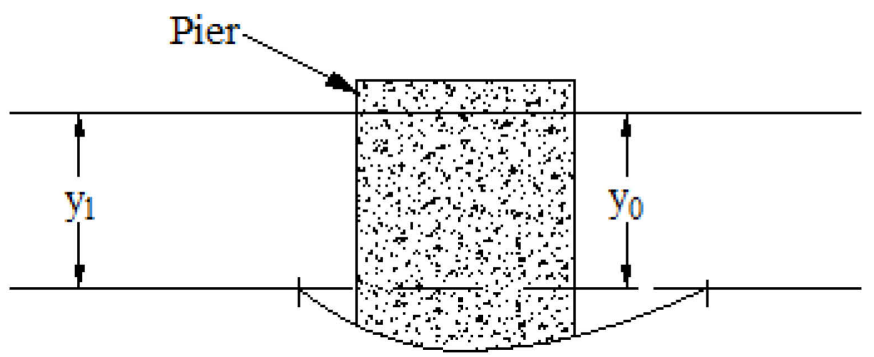

b)

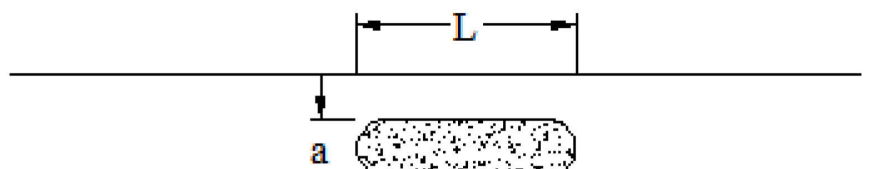

c)
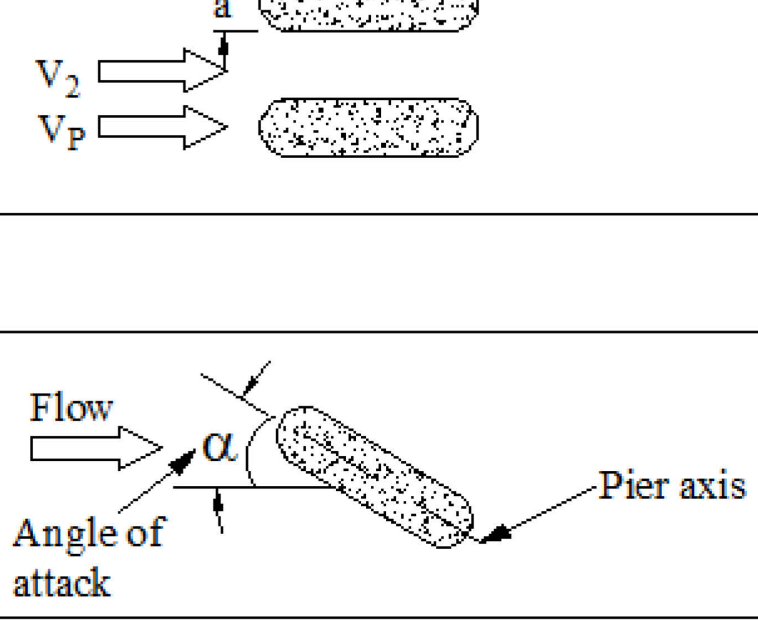

Figure 1. Schematic of a) river cross section along the pier, b) plan view of piers within the river c) plan view of pier with angle of flow within the river

A summary of all methods and their features used in this paper are presented in Table 3. Out of the five, two methods are suitable for scour prediction of cohesive soil. Although, every site in this study have cohesive soil, non-cohesive methods such as old HEC - 18 and FDOT methods are also used for the comparison of estimated scour with the scour depth obtained the from cohesive methods. 
Table 1. Soil properties of the river and hydraulics data at upstream of the bridge site.

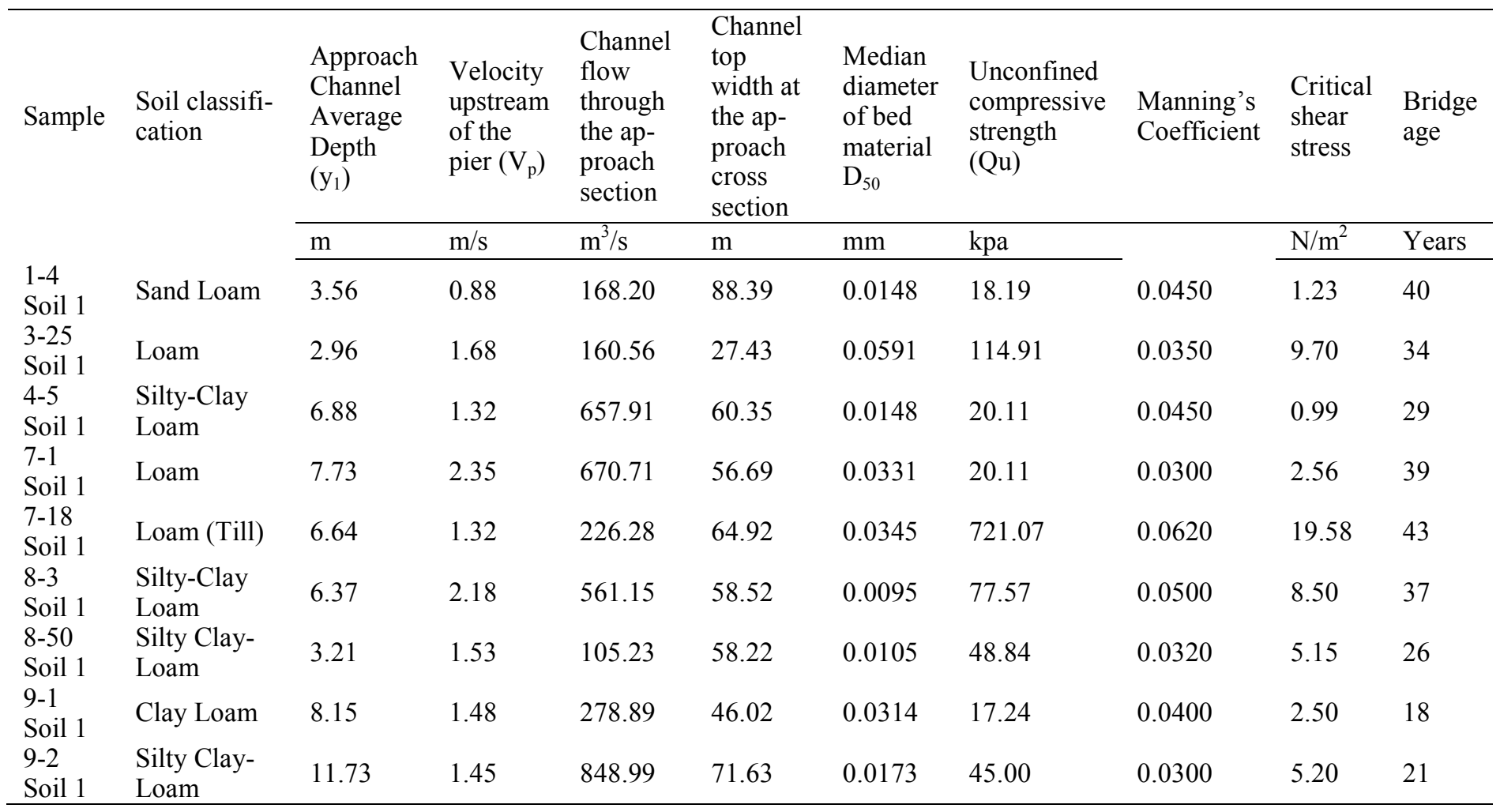

Table 2. Pier information and hydraulics data at the location of bridge

\begin{tabular}{|c|c|c|c|c|c|c|c|c|}
\hline Sample & $\begin{array}{l}\text { Pier } \\
\text { shape }\end{array}$ & $\begin{array}{l}\text { Pier } \\
\text { length } \\
\text { (L) }\end{array}$ & $\begin{array}{l}\text { Pier } \\
\text { width } \\
\text { (a) }\end{array}$ & $\begin{array}{l}\text { Angle of } \\
\text { attack }(\alpha)\end{array}$ & $\begin{array}{l}\text { Existing } \\
\text { bridge con- } \\
\text { traction } \\
\text { channel av- } \\
\text { erage depth } \\
\left(\mathrm{y}_{0}\right)\end{array}$ & $\begin{array}{l}\text { Contracted } \\
\text { channel av- } \\
\text { erage veloci- } \\
\text { ty }\left(\mathrm{V}_{2}\right)\end{array}$ & $\begin{array}{l}\text { Flow chan- } \\
\text { nel through } \\
\text { the bridge } \\
\text { opening }\end{array}$ & $\begin{array}{l}\text { Channel top width in- } \\
\text { side the bridge opening }\end{array}$ \\
\hline & & $\mathrm{m}$ & $\mathrm{m}$ & degree & $\mathrm{m}$ & $\mathrm{m} / \mathrm{s}$ & $\mathrm{m}^{3} / \mathrm{s}$ & $\mathrm{m}$ \\
\hline 1-4 Soil 1 & Round & 15.18 & 0.91 & 0 & 4.34 & 0.88 & 180.32 & 43.28 \\
\hline 3-25 Soil 1 & Round & 14.02 & 0.76 & 0 & 3.40 & 1.68 & 151.95 & 25.30 \\
\hline 4-5 Soil 1 & Round & 12.80 & 1.22 & 0 & 8.99 & 1.32 & 1084.31 & 44.81 \\
\hline 7-1 Soil 1 & Round & 10.97 & 0.86 & 0 & 7.80 & 2.35 & 916.19 & 46.94 \\
\hline 7-18 Soil 1 & Round & 60.96 & 0.84 & 0 & 5.89 & 1.32 & 459.75 & 59.13 \\
\hline 8-3 Soil 1 & Square & 8.02 & 0.91 & 0 & 6.84 & 2.18 & 864.65 & 53.64 \\
\hline 8-50 Soil 1 & Round & 10.76 & 0.91 & 0 & 2.48 & 1.53 & 128.13 & 22.25 \\
\hline 9-1 Soil 1 & Round & 10.67 & 0.76 & 0 & 7.15 & 1.48 & 587.94 & 54.86 \\
\hline 9-2 Soil 1 & Round & 11.89 & 1.46 & 0 & 10.70 & 1.45 & 1125.54 & 66.75 \\
\hline
\end{tabular}

Table 3. Scour prediction methods

\begin{tabular}{|c|c|c|c|c|c|}
\hline $\begin{array}{l}\text { Scour } \\
\text { prediction } \\
\text { methods }\end{array}$ & $\begin{array}{l}\text { Pier } \\
\text { scour }\end{array}$ & $\begin{array}{l}\text { Contraction } \\
\text { scour }\end{array}$ & $\begin{array}{l}\text { Applicable } \\
\text { to cohesive } \\
\text { soil }\end{array}$ & $\begin{array}{l}\text { Applicable to } \\
\text { non-cohesive } \\
\text { soil }\end{array}$ & $\begin{array}{l}\text { Scour prediction } \\
\text { for any number } \\
\text { of years since } \\
\text { construction }\end{array}$ \\
\hline Old HEC -18 & Yes & Yes & No & Yes & No \\
\hline Modified HEC - 18 & Yes & Yes & Yes & No & Yes \\
\hline SRICOS & Yes & Yes & Yes & No & Yes \\
\hline FDOT & Yes & No & No & Yes & No \\
\hline
\end{tabular}

*Reduction factor method can be applied only to the total scour depth (pier + contraction scour) 


\subsection{SRICOS Method}

Briaud et al. (1999) developed this method for the prediction of pier scour around cylindrical piers in cohesive soil. This method incorporates an EFA test in which soil from the site is tested at different water velocities in an EFA machine and the corresponding erosion rate is obtained. Consequently, an erosion function curve (i.e., erosion rate vs shear stress) is obtained. The maximum shear stress induced in the river can be calculated from Eq. (1) and the initial rate of scour $\left(\mathrm{z}_{\mathrm{i}}\right)$ corresponding to this maximum shear stress is obtained from the erosion function curve.

$\tau_{\max }=0.094 \rho v^{2}\left(\frac{1}{\log \mathrm{Re}}-\frac{1}{10}\right)$

where $\rho$ is the density of water $\left(\mathrm{kg} / \mathrm{m}^{3}\right) ; \mathrm{Re}=\mathrm{vD} / v$ is the Reynolds Number with the pier diameter D (in metres); $v$ is the kinematic viscosity of water $\left(10^{-6}\right.$ $\mathrm{m}^{2} / \mathrm{s}$ at $20^{\circ} \mathrm{C}$ ) and $\mathrm{v}$ is the mean velocity of water in the river $(\mathrm{m} / \mathrm{s})$. The ultimate depth of pier scour is calculated from Eq. (2):

$$
\mathrm{Z}_{\text {max }, \mathrm{p}}=0.018 \mathrm{Re}^{0.635}
$$

This ultimate pier scour depth around a pier is obtained for infinite time (i.e., $t=\infty$ ) and it is also independent of soil properties in this form. However, to predict the pier scour depth for the number of years passed, the ultimate scour depth and initial rate of scour is used in Eq. (3).

$\mathrm{z}=\frac{\mathrm{t}_{\mathrm{e}}}{\frac{1}{\mathrm{z}_{\mathrm{i}}}+\frac{\mathrm{t}_{\mathrm{e}}}{\mathrm{z}_{\mathrm{max}, \mathrm{p}}}}$

where $t_{e}$ is the equivalent time (in hours), which is defined as the time required for the maximum velocity in the river hydrograph to produce the same scour depth as produced by the complete hydrograph. Hydrograph data for nine rivers in Illinois were extracted from Straub et al. (2010). $Z_{i}$ is the initial rate of scour corresponding to the maximum shear stress obtained from the erosion function curve. For the prediction of ultimate contraction scour depth at the time infinity using this method, Eq. (4) is used.

$\mathrm{Z}_{\text {max }, \mathrm{c}}=1.90\left(\frac{1.49 \mathrm{~V}_{2}}{\sqrt{\mathrm{gH}_{1}}}-\frac{\left(\frac{\tau_{\mathrm{c}}}{\rho}\right)^{2}}{\mathrm{gnH}_{1}^{\frac{1}{3}}}\right) \mathrm{H}_{1}$

where $Z_{\text {max,c }}$ is the maximum contraction scour (m); $V_{2}$ is the mean velocity in the contracted section $(\mathrm{m} / \mathrm{s}) ; \mathrm{g}$ is the acceleration due to gravity $\left(\mathrm{m} / \mathrm{s}^{2}\right)$; $\mathrm{H}_{1}$ is the water depth in the approach section (m), $\mathrm{n}$ is the manning's coefficient, and $\tau_{\mathrm{c}}$ is the critical shear stress $(\mathrm{Pa})$. Moreover, to predict the contraction scour for the number of years passed, Eq. (3) is used and only the parameter $Z_{\max , p}$ is replaced by $Z_{\text {max,c. }}$

\subsection{Hydraulic Engineering Circular No. 18 (HEC- 18)}

The scour depth for both cohesive and non-cohesive soils can be determined through this method. The scour equation for non-cohesive soil is known as the old HEC - 18 equation and is applicable for both clear water and live bed scour. Eq. (5) is used to calculate pier scour through the old HEC - 18 method.

$\frac{\mathrm{y}_{\mathrm{s}}}{\mathrm{y}_{1}}=2 \mathrm{k}_{1} \mathrm{k}_{2} \mathrm{k}_{3}\left(\frac{\mathrm{a}}{\mathrm{y}_{1}}\right)^{0.65} \mathrm{Fr}^{0.43}$

where, $\mathrm{y}_{\mathrm{s}}$ is the pier scour depth (m), $\mathrm{k}_{1}$ is the correction factor for shape of the pier. Value of $k_{1}$ is equal to 1 and 1.1 for round and square nose pier shapes, respectively. $\mathrm{k}_{2}$ is the correction factor for angle of attack and is equal to 1 for zero degree angle of flow. $\mathrm{k}_{3}$ is the correction factor for bed condition and is equal to 1.1 for clear water scour and $\mathrm{a}$ is the pier width $(\mathrm{m}) . \mathrm{y}_{1}$ is the flow depth $(\mathrm{m})$ and $\mathrm{v}_{\mathrm{p}}$ is the velocity $(\mathrm{m} / \mathrm{s})$ both being directly upstream of the pier. $\mathrm{Fr}=\mathrm{v}_{\mathrm{p}} /\left(\mathrm{gy}_{1}\right)^{0.5}$ is the Froude number.

In addition, Arneson et al. (2012) also developed an equation to predict ultimate pier and contraction scour depth in a cohesive soil, also known as modified HEC - 18 equation. The pier scour depth through this method can be determined from Eq. (6), which is dependent on the critical velocity (i.e., velocity required for the initiation of scour) of soil.

$\mathrm{y}_{\max , \mathrm{p}}=2.2 \mathrm{k}_{1} \mathrm{k}_{2} \mathrm{a}^{0.65}\left(\frac{2.6 \mathrm{~V}_{\mathrm{P}}-\mathrm{V}_{\mathrm{C}}}{\sqrt{\mathrm{g}}}\right)^{0.7}$

where $\mathrm{v}_{\mathrm{c}}$ is the critical velocity $(\mathrm{m} / \mathrm{s})$. All other all parameters are the same as used in old HEC - 18 equation. To determine the contraction scour, the shear stress induced by the flowing water over the soil is calculated using Eq. (7) and then is compared with the critical shear stress.

$\tau=\gamma\left(\frac{\mathrm{V}_{2} \mathrm{n}}{\mathrm{K}_{\mathrm{u}}}\right)^{2} \mathrm{y}_{0}^{-1 / 2}$

where $\tau$ is the shear stress $\left(\mathrm{N} / \mathrm{m}^{2}\right)$; $\gamma$ is the specific weight of water $\left(\mathrm{N} / \mathrm{m}^{3}\right) ; y_{0}$ is the existing depth of flow in the contracted bridge section before scour (m) and $K_{u}$ is a constant (equal to 1). Contraction scour does not exist if this induced stress is less than the critical shear stress. All formulae to calculate ultimate contraction scour depth through old and modified HEC - 18 method are not repeated in this paper, but can be found from Arneson et al. (2012) fifth edition of HEC -18 manual. The ultimate scour depth values from this method along with $Z_{i}$ obtained from EFA curve can be used collectively in 
Eq.(3) to predict scour depth for any number of years passed from the bridge construction date.

\subsection{Cohesive soil reduction factor method}

Since the old HEC - 18 method predicts higher scour depth for cohesive soils, this method is revised to obtain a more reasonable estimate of predicted scour depth. For the range of unconfined compressive strength of the soil, Straub et al. (2013) determined reduction factors as presented in Table 4. Corresponding to these strength ranges of soil, reduction factors are applied to the total ultimate scour depth obtained from old HEC - 18 method to estimate the erosion rate for cohesive materials.

Table 4. Cohesive Soil Reduction Factors for Ranges of Unconfined Compressive strength $\left(\mathrm{Q}_{\mathrm{u}}\right)$

\begin{tabular}{ll}
\hline $\begin{array}{l}\text { Unconfined compressive } \\
\text { strength }\end{array}$ & $\begin{array}{l}\text { Percent Reduction in } \\
\text { Scour Depth }\end{array}$ \\
\cline { 1 - 2 } kpa & \\
\hline$>143.64$ & 50 \\
$47.88-143.64$ & 25 \\
$<47.88$ & 0 \\
\hline
\end{tabular}

\subsection{Florida Department of Transportation (FDOT) method}

The Florida Department of Transportation has developed a methodology to calculate pier scour in non-cohesive soil. However, in the case of contraction scour, the same equation offered by old HEC -18 for non-cohesive soil is used. This method is applicable for estimation of pier scour in a river having shallow flow depth with a fine bed material and wide piers. A ratio of upstream flow depth to pier width of less than 0.2 is suggested. All the details of pier scour calculation through this method can be found in Arneson et al. (2012).

\section{RESULT AND DISCUSSION}

\subsection{Ultimate Scour prediction}

Ultimate depths of scour, which includes pier and contraction scour, for nine bridge sites in Illinois were calculated through all aforementioned methods. Figure 2 shows the predicted ultimate scour depths from five different methods. On average, as expected non-cohesive methods predicted scour depths substantially larger than both cohesive methods, i.e., SRICOS and the modified HEC -18. The FDOT method predicted the highest ultimate scour depth on $56 \%$ (5 out of 9) bridge sites followed by old HEC -18, whereas the SRICOS method predicted the lowest scour depth except for Site 3-25. It is shown in Figure 2, that the FDOT method predicted ultimate depths of scour $1.15 \mathrm{~m}$ to $6.64 \mathrm{~m}$ more than the SRICOS method for $89 \%$ of bridge sites, except Site $3-25$, by a factor of 2.4 on average. In a comparative study among all five methods, at Site 7-18, highest range of scour was obtained with the scour depth ranging from $2.30 \mathrm{~m}$ to $8.94 \mathrm{~m}$.

Similarly, another non-cohesive method, old HEC - 18 method also predicted greater scour depths compared with the cohesive methods i.e., SRICOS and modified HEC - 18. In comparison with SRICOS, old HEC- 18 predicted total ultimate scour depths $1.29 \mathrm{~m}$ to $6.41 \mathrm{~m}$ greater on $89 \%$ bridge sites (i.e., except Site 3-25). Moreover, comparing only cohesive methods i.e., modified HEC -18 and SRICOS, the former method predicted $0.42 \mathrm{~m}$ to $1.36 \mathrm{~m}$ (i.e., $17.79 \%$ to $60.63 \%$ ) greater ultimate scour depth at all sites. With the exception of Site 1-4, On average, scour prediction using modified HEC - 18 was $27 \%$ greater than SRICOS. It is notable that modified HEC - 18 predicted scour depth greater by a factor of 1.31 than the SRICOS method. This implies, both cohesive methods of scour predictions gives us a reasonable estimate when applied for cohesive soil, however both of them are conservative. It is worth mentioning that, when all aforementioned methods are applied for cohesive soil, the noncohesive methods predicted scour depths greater by a factor of 1.89 than the cohesive methods.

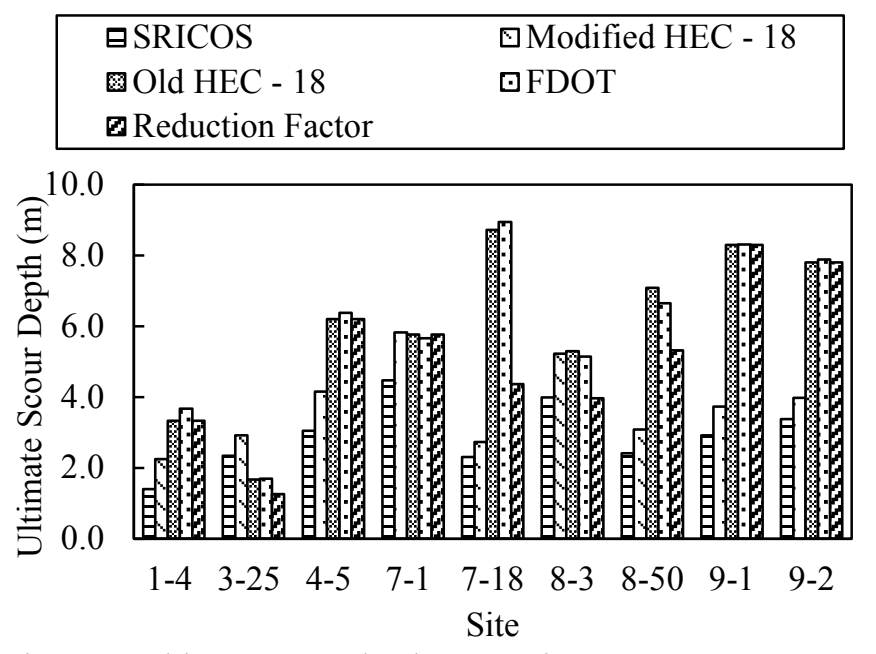

Figure 2. Ultimate scour depth comparison

\subsection{Comparison of pier and contraction scour}

The pier and contraction scour depths from old HEC - 18, modified HEC - 18 and SRICOS methods for all nine bridge sites in Illinois were compared separately to determine the contribution of each type of scour on the total scour. As shown in Figure 3, at $67 \%$ (6 out of 9) bridge sites, the modified HEC 18 method predicted greatest pier scour depths whereas the SRICOS method predicted the lowest. The modified HEC - 18 approach predicted ultimate depths of pier scour $0.03 \mathrm{~m}$ to $0.82 \mathrm{~m}$ greater at $67 \%$ bridge sites compared to old HEC - 18, and $0.40 \mathrm{~m}$ 
to $1.07 \mathrm{~m}$ greater at all bridge sites compared to the SRICOS method.

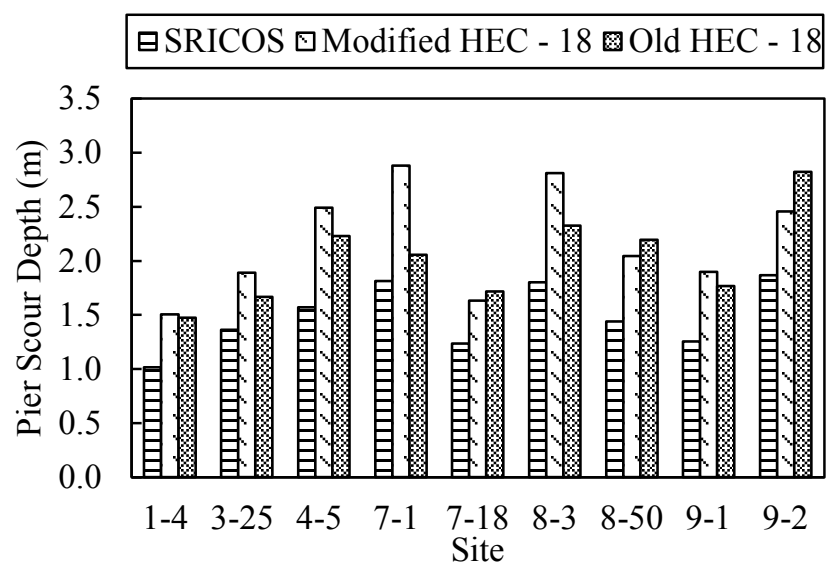

Figure 3. Predicted pier scour depth

Similarly, in the case of ultimate depth of contraction scour, except Site 3-25, old HEC - 18 method predicted contraction scour significantly greater than modified HEC - 18 and SRICOS method. As presented in Figure 4, at $89 \%$ of bridge sites, the old HEC - 18 method predicted contraction scour 0.55 $\mathrm{m}$ to $5.91 \mathrm{~m}$ greater compared to modified HEC -18 and $0.78 \mathrm{~m}$ to $5.93 \mathrm{~m}$ greater compared to SRICOS method. In other words, with the exception of Site 325 , on average, the contraction scour depths using old HEC - 18 were greater than modified HEC - 18 and SRICOS by a factor of 3.17 and 3.64, respectively. At Site 3-25, there was not any contraction scour. The predicted scour depths using modified HEC-18 and SRICOS methods are in reasonable agreement.

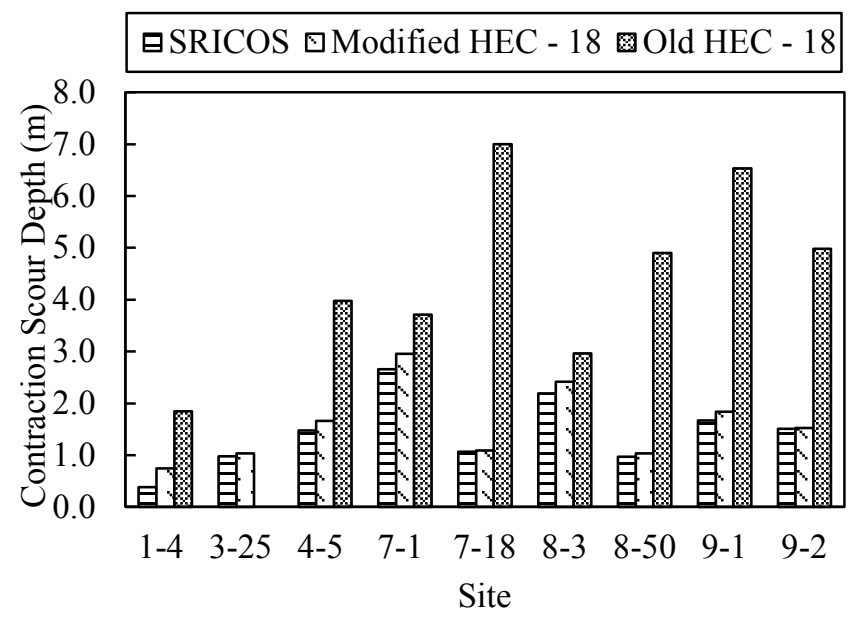

Figure 4. Predicted contraction scour depth

Hence, in this comparative study, the SRICOS method predicted the lowest pier or contraction scour depth among the prediction methods considered. On average, pier scour was about 1.5 more than contraction scour in SRICOS and modified
HEC - 18 methods. In the case of old HEC -18 method, on average, contraction scour was more than twice the pier scour.

\subsection{Comparison of predicted scour with measured scour}

In 2005, both pier and contraction scour depth that occurred at all bridge sites from the date of construction of bridges were measured. Total scour predictions from cohesive methods were compared with these measured scour depths. As presented in Figure 5, for all sites except Site 9-2, (i.e., 89\% bridge site), modified HEC - 18 method predicted $0.52 \mathrm{~m}$ to 1.89 $\mathrm{m}$ greater pier and contraction scour depth than what was measured. This is equivalent to a factor of 2.1 times greater scour depths on average. Furthermore, at $78 \%$ bridge sites (i.e., except Site 1-4 and 9-2), SRICOS method also predicted $0.21 \mathrm{~m}$ to $1.21 \mathrm{~m}$ greater scour depth compared to measured scour. This is equivalent to a factor of 1.7 greater scour depths on average.

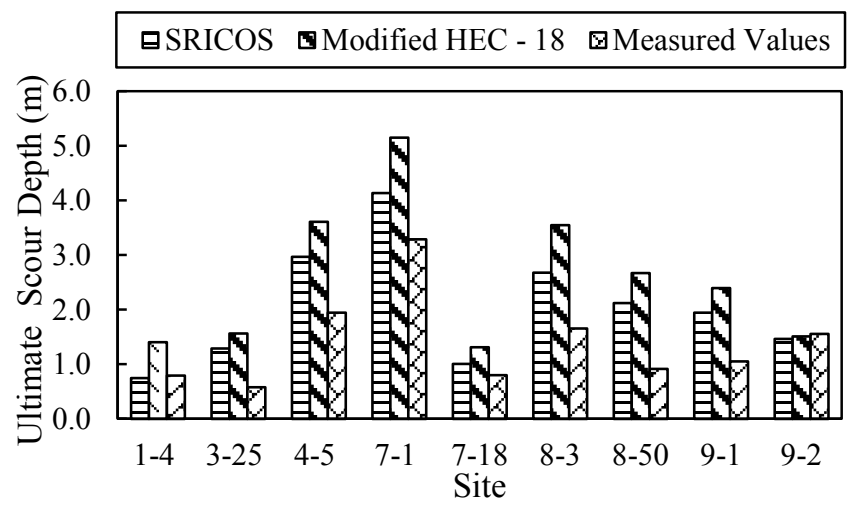

Figure 5: Predicted vs measured scour depths

These predicted scour depths from both methods were also compared graphically, as shown in Figure 6. As presented in Figure 6, when the measured scour depths were less than $2 \mathrm{~m}$, there were not significant differences between the predicted scour from modified HEC-18 and SRICOS with the measured values. However, as the depths of the measured scour increased, deviations of predicted scour from both SRICOS and modified HEC - 18 methods with measured scour increased. It is worth mentioning that, these measured values have not reached an equilibrium condition and are increasing very slowly over time. On top of these facts, it can be concluded that the scour prediction from both SRICOS and modified HEC - 18 are in a reasonable agreement with each other, however, both of them are conservative on average by a factor of 1.72 and 2.11 , respectively. 


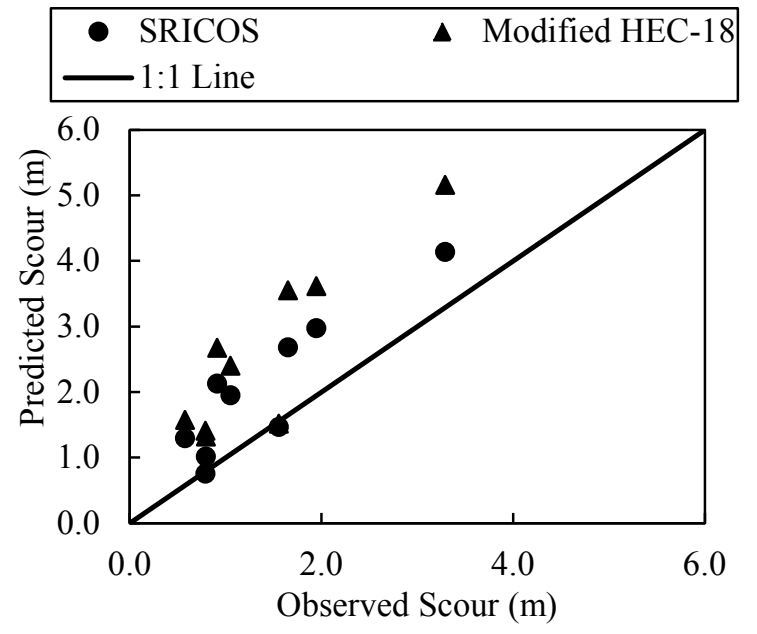

Figure 6. Comparison of predicted and measured scour

\section{CONCLUSION}

For nine bridge sites in Illinois, ultimate scour depths were predicted through five different methods. On average, the FDOT method predicted the highest scour (i.e., pier and contraction) depth followed by old HEC - 18, reduction factor, modified HEC- 18 and the SRICOS method. On average, the non-cohesive methods considered predicted values of ultimate scour depth that were 1.9 times greater than the cohesive methods applied. The modified HEC - 18 approach predicted ultimate scour depths that were 1.3 times greater than SRICOS.

From a comparative study of pier and contraction scour, it was concluded that, on average, pier scour had more contribution than contraction scour in SRICOS and the modified HEC - 18 method. The ultimate pier scour was greater by a factor of 1.50 and 1.58 , respectively than the contraction scour. However, in the case of the old HEC - 18 method, on average, contraction scour was more than double compared to the pier scour and was greater by a factor of 2.23 .

In the case of real time prediction of scour, both SRICOS and modified HEC -18 predicted greater than what was measured at the sites. At $89 \%$ bridge site, modified HEC - 18 predicted $0.52 \mathrm{~m}$ to $1.89 \mathrm{~m}$ greater pier and contraction scour depth than the measured one. Similarly, at $78 \%$ bridge sites, SRICOS method predicted $0.21 \mathrm{~m}$ to $1.21 \mathrm{~m}$ greater scour depth compared to measured scour. The scour prediction in modified HEC - 18 and SRICOS were in reasonable agreement with each other but both were conservative by a factor of 2.11 and to 1.72 , respectively.

\section{REFERENCES}

Arneson, L. A., Zevenbergen, L. W., Lagasse, P. F., \& Clopper, P. E. (2012). Evaluating Scour at Bridges. US Department of Transportation Federal Highway Administration.

Briaud, J. L. (2014). Scour Depth at Bridges: Methods Including Soil Properties . II: Time Rate of Scour Predciction. Journal of Geotechnical and Geoenvironmental Engineering.

Briaud, J. L., Chen, H. C., Chang, K. A., Oh, S. J., \& Chen, x. (2009).Abutment Scour in Cohesive Material. Transportation Research Board, National Research Council.

Briaud, J. L., Chen, H. C., Chang, K. A., OH, S. J., Chen, S., Wang, J., . . . Ting, F. (2011). The Sricos-EFA Method. Texas A\&M University.

Briaud, J. L., Chen, H. C., Li., Y., Nurtjahyo, P., \& Wang, J. (2004). Pier and Contraction Scour in Cohesive Soils.

Briaud, J. L., Govindasamy, A. V., Kim, D., Gardoni, P., Olivera, F., Chen, H. C., . . . Elsbury, K. (2008). Simplified method for estimating scour at bridges. Texas Transportation Institute, Texas A\&M university System.

Briaud, J. L., Ting, C. K., Chen, H. C., Gudavalli, R., Wei, G., \& Perugu, S. (1999). Predicition of Scour Rate in Cohesive Soils at Bridge Piers. Journal of Geotechnical and Geoenvironmental Engineering.

Ghelardi, V. M. (2004). Estimation of long term bridge pier socur in cohesive soils at maryland bridges using EFA/SRICOS.

Institute, T. T. (n.d.). SRICOS: Prediction of Scour Rate at Bridge Piers.

Sheppard, D. M., Demir, H., \& Melville, B. (2011). Scour at Wide Piers and Long Skewed Piers.

Straub, T. D., \& Over, T. M. (2010). Pier and Contraction Scour Preditction in Cohesive Soils at Selected Bridges in Illinois. Springfield: Illinois Department of Transportation.

Straub, T. D., Over, T. M., \& Domanski, M. M. (2013). Ultimate Pier and Contraction Scour Prediction in Cohesive Soils at Selected Bridges in Illinois. Springfield: Illinois Department of Transportation

Wang, J. (2004). The SRICOS-EFA method for complex pier and contraction scour. 